\title{
Strategizing in English hospitals: Accounting, practical coping and strategic intent
}

DOI:

10.1108/AAAJ-11-2017-3211

\section{Document Version}

Accepted author manuscript

Link to publication record in Manchester Research Explorer

\section{Citation for published version (APA):}

Begkos, C., Llewellyn, S., \& Walshe, K. (2019). Strategizing in English hospitals: Accounting, practical coping and strategic intent. Accounting, Auditing and Accountability Journal, 32(5), 0. https://doi.org/10.1108/AAAJ-11-20173211

\section{Published in:}

Accounting, Auditing and Accountability Journal

\section{Citing this paper}

Please note that where the full-text provided on Manchester Research Explorer is the Author Accepted Manuscript or Proof version this may differ from the final Published version. If citing, it is advised that you check and use the publisher's definitive version.

\section{General rights}

Copyright and moral rights for the publications made accessible in the Research Explorer are retained by the authors and/or other copyright owners and it is a condition of accessing publications that users recognise and abide by the legal requirements associated with these rights.

\section{Takedown policy}

If you believe that this document breaches copyright please refer to the University of Manchester's Takedown Procedures [http://man.ac.uk/04Y6Bo] or contact uml.scholarlycommunications@manchester.ac.uk providing relevant details, so we can investigate your claim.

\section{OPEN ACCESS}




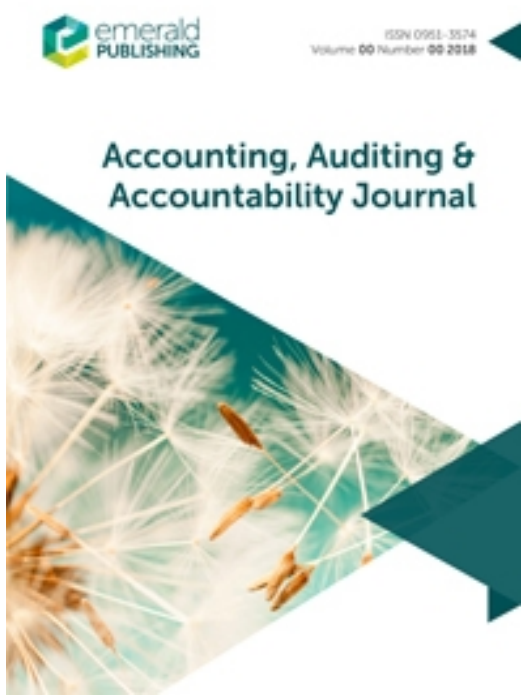

\section{Strategizing in English hospitals: Accounting, practical coping and strategic intent}

\begin{tabular}{|r|l|}
\hline Journal: & Accounting, Auditing \& Accountability Journal \\
\hline Manuscript ID & AAAJ-11-2017-3211.R2 \\
\hline Manuscript Type: & Research Paper \\
\hline Keywords: & strategizing, strategy, pathway, pluralism, healthcare, strategic intent \\
\hline
\end{tabular}




\title{
Strategizing in English hospitals: Accounting, practical coping and strategic intent
}

\begin{abstract}
Purpose: The purpose of this paper is to investigate the intricate ways in which accounting is implicated in the unfolding of strategizing in a pluralistic setting. The authors treat strategizing as a practical coping mechanism which begins in response to a problem and unfolds over time into an episode. This approach enables the authors to explore strategizing pathways and the ways they can mobilise accounting to advance from practical coping to explicit strategic intent.

Design/methodology/approach: The authors conducted semi-structured interviews with Clinical Directors, Business Managers and Finance personnel at three NHS hospitals. Documents were also collected, such as business cases and financial reports. The authors employed theories on strategizing agency, episodes and practical coping to select examples of strategizing and indicate how strategizing is constructed and performed. We present the results of this qualitative analysis in three strategizing narratives.
\end{abstract}

Findings: The analysis highlights how Clinical Directors' strategizing with accounting, in response to their financial problems, can take on contesting, conforming and circumventing modes. As the strategizing pathway unfolds, accounting acts as an obligatory passage point through which Clinical Directors pursue their strategic intent. Along each pathway we identify, first, where practical coping takes on a clear strategic intent and, second, whether this emergent strategy proves efficacious.

Originality/value: The authors contribute to the nascent body of accounting and strategizing studies through seeing strategizing with accounting, not as the formulation of explicit organizational strategy as 'done' in board rooms and strategy meetings, but as an impromptu response to a critical financial problem within a localised organizational setting. In response to a problem, actors may realise their immanent strategizing through their engagement with accounting practices.

Keywords: strategizing, strategy, NHS, episode, strategic intent, pathway, pluralism, healthcare

Paper type: Research paper 


\section{Introduction}

A traditional definition of strategy is "the determination of the long-term goals and objectives of an enterprise, and the adoption of courses of action and the allocation of resources necessary for carrying out these goals" (Chandler, 1962, p. 13). This definition highlights two broad aspects of strategy: first, the formulation of organisational strategy and second, the resource allocations required to implement the strategy. Early accounting and strategy research addressed the latter, focussing on the role of accounting in how strategy is implemented and finding optimal ways of allocating resources to achieve implementation. Such research treated strategy as fairly stable and discrete, offering insight into how accounting achieved pre-determined strategic objectives, thus reducing accounting to an 'output' of strategy, neglecting its transformative and constitutive powers (Boedker, 2010).

In contrast, over the last decade, an emerging stream of research on accounting and strategy practices has shed light on the relationship between accounting and the formulation of strategy. Such studies treat accounting and strategy as situated social practices through exploring action at the micro level (Ahrens \& Chapman, 2007; Chua, 2007; Johnson et al., 2003; Whittington, 1996). This recent practice perspective views strategy not as something that an organization has, but as something that its members do, thus shifting the focus to the notion of 'strategizing', which is broadly understood as the 'doing' of strategy.

Jarzabkowski et al. (2007, p. 7-8) suggest that "strategizing comprises those actions, interactions and negotiations of multiple actors and the situated practices that they draw upon in accomplishing that activity", indicating that actors enact strategy through their day-to-day, micro-activities (Jarzabkowski et al., 2007; Johnson et al., 2003; Whittington, 2003; 2006). This framing treats strategizing as a complex entanglement of activities, practices and the agents who perform them.

Most strategizing studies investigate the activities of actors who are "involved in, or seeking to influence, strategy-making" (Vaara \& Whittington, 2012, p. 290); focussing on actors who engage in shaping the formal strategic orientation of their business unit. Accounting and strategizing studies have also looked at formal and explicit strategizing activities, such as how diverse actors use accounting to devise (e.g. Denis et al., 2006; Maclntosh \& Beech, 2011; Whittle \& Mueller, 2010), consume (e.g. Fauré \& Rouleau, 2011) and transform (e.g. Skærbæk \& Tryggestad, 2010) explicit organizational strategy.

One critique of such studies is that "Strategy-making does not always involve the necessary formulation of goals, mental maps or plans" (Chia \& Mackay, 2007, p. 238). Llewellyn (2001) suggests that, when actors strategize, they navigate, plan and perform their day-to-day activities in particular ways, in an attempt to steer their organizations in a certain strategic direction. Others suggest that strategy and strategists may only be understood retrospectively through situated practices (Carter et al., 2008; Tsoukas, 2010). Strategy is immanent in everyday practical coping and adaptive action, in the sense that actors can begin to manifest strategic intent when they engage in ordinary organizational tasks because there is an "immanent logic of practice" (Chia \& Mackay, 2007, p. 219; see also Chia \& Holt, 2006). 
Despite the plethora of recent strategizing research, there is a notable paucity of research that treats strategizing as an everyday practical coping mechanism, through which actors spontaneously respond to their organizing problems which may link into strategic issues (e.g. Chia \& Rasche, 2010; Tsoukas, 2010). We conceptualize strategizing as practical coping to address a problem, where an agent's clear strategic intent can become manifest in everyday practice whilst addressing a problem. Strategic intent is characterized by a clear sense of purpose (Mantere \& Sillince, 2007), conveys strategic direction and can actively steer resource allocation (Hamel \& Prahalad, 1990; O'Shannassy, 2016). We argue that strategic intent, as a "proactive mode in strategizing" (Mantere \& Sillince, 2007, p. 407) can be triggered through engaging in operational decision-making whenever this is suggestive of a new option with strategic implications.

This paper adopts this notion of strategizing through identifying the intricate ways in which clinicians use accounting to strategize in their Clinical Directorates. In doing so, we contribute to the nascent body of accounting and strategizing studies through seeing strategizing with accounting, not as the formulation of explicit organizational strategy as 'done' in board rooms and strategy meetings, but as an impromptu response to a critical financial problem within a localised organizational setting.

In strategizing research there is a surprising lack of attention on how strategizing begins, unfolds and ends in practice. Some authors suggest that strategizing, as a coping mechanism, may begin in response to an unexpected event or immediate impediment (e.g. Chia \& Rasche, 2010; Tsoukas, 2010). Authors who envisage strategizing as enacted through distinct stages suggest that a strategizing episode begins when operational routines are suspended, actors reflect on explicit practice and, then, engage with strategic issues (e.g. Hendry \& Seidl, 2003; Maitlis \& Lawrence, 2003). We treat strategizing as a process which starts in response to a problem and develops over time into an episode. This approach allows us to focus on strategizing pathways and the ways they unfold through, around or in conflict with accounting. We argue that engaging with accounting can trigger strategic intent at some point in the episode - thus giving practical coping strategic direction.

Our research is in healthcare, specifically, English NHS hospitals. We are interested in the strategizing of Clinical Directors - senior clinicians who have both financial and clinical responsibilities for their Directorates, which have now assumed profit centre status. Profit centre standing is significant because it can provide the rationale for Clinical Directors' strategizing towards achieving what now makes sense to them, for example, boosting the profitability of their Directorates and using this evidence to achieve investment. Clinical Directors are a hybrid profession of medical professionals who engage with accounting (Jacobs, 2005; Kurunmäki, 2004; Llewellyn, 2001) to effectively manage their financial responsibilities and, where they can, secure additional resources for their Directorates. Our Clinical Directors are not qualified accountants (Ezzamel \& Willmott, 2008) but nor are they "accountants in the wild" (Skærbæk \& Tryggestad, 2010) because they have acquired financial expertise either through their work, which necessitates financial acumen, or obtaining a formal qualification - such as an MBA (Begkos, 2016; Llewellyn et al., 2016).

Strategizing, rather than explicit strategy, is inherent in pluralistic organizations because they encompass multiple actors with diverse interests - a potent mix which generates ambiguous strategic goals (Denis et al., 2006). Healthcare is inherently pluralistic, accommodating "multiple objectives, diffuse power and knowledge-based work processes" (Denis et al., 2007, p. 179-180) in 
a single domain. Hospitals host a multiplicity of professional and managerial cultures and interests which may, ultimately, be impossible to reconcile (Jarzabkowski \& Fenton, 2006). For example, the formal role of Clinical Directors is required to balance the diverse objectives of patient care, population health, cost control and the financial viability of both the hospital and their clinical units (Denis et al., 2001; Denis et al., 2007).

In sum, this paper adopts a notion of strategizing as purposive, non-deliberate practical coping that is triggered by a problem. We trace Clinical Directors' strategizing pathways in NHS hospitals. Our research question is: How is accounting implicated in the unfolding of strategizing in a localised unit within a pluralistic hospital setting? Our findings extend the limited body of accounting and strategizing studies which conceptualize strategizing as a practical coping mechanism. We draw on our empirical findings to contribute to this research by identifying when and how practical coping becomes more explicitly strategic through engagement with accounting. We also enhance specific knowledge on the implications of accounting for actors' strategizing in pluralistic organizations.

The paper is structured as follows: first, theoretically, we locate our study within the strategizing research. We then provide a brief background section that explores the roles and responsibilities of Clinical Directors in the, recently established, profit centres in NHS hospitals. The next section details our methodology, which is followed by the three narratives which trace the adaptive pathways forged as the Clinical Directors strategize. The paper concludes with a discussion of the role of accounting for strategizing pathways where we highlight our contribution.

\section{Conceptual background: strategizing as episodic, agential, practical coping}

This section delineates our theoretical framework, which encompasses strategizing practices, episodes and agency. Within this work we focus on strategizing agents who, generally, are not deemed strategists and whose work may not, prima facie, appear as strategic. Here, strategizing is treated as episodic, non-deliberate yet purposive practical coping.

\section{Strategizing as practical coping}

Ever since Mintzberg's (1987) work on crafting strategy, strategizing- the 'doing', rather than the 'having' of strategy, has garnered increasing interest (Whittington, 1996; Johnson et al., 2003; Jarzabkowski et al., 2007; Jørgensen \& Messner, 2010). Verbs, like 'strategizing', are privileged over nouns, like 'strategy', whenever organizations are seen as inherently processual and pluralistic rather than as states which can achieve equilibrium (Chua, 2007; Denis et al., 2007; Weick, 1969).

As noted above, we view strategizing as a practical coping mechanism (e.g. Chia \& Holt, 2006; Chia \& MacKay, 2007; Chia \& Rasche, 2010; see also Tsoukas, 2010; Hydle, 2015). Chia and Holt (2006), inspired by Heidegger (1971), use the term "dwelling" to describe strategizing as a purposive, practical coping mechanism that is characterized by an "internalized modus operandi" to adapt to the local environment. Dwelling is opposed to a "building" view of agency where strategizing is formal and intentional with deliberate premeditated objectives for the organization as a whole (Chia \& Holt, 2006, p. 644). They also argue that strategizing usually takes place while actors are in a dwelling state, where the identities and strategies of the strategizing agents are simultaneously co-created by means of interacting with their pluralistic 
social environment. In this sense, activities are deemed strategic and actors are deemed strategists ex post to actors' strategizing activities. Chia and Rasche (2010) expand on the notion of purposive but non-deliberate strategizing, suggesting that it requires practical wisdom and practical intelligence (which they term as "phronesis" and "metis" respectively) to instinctively and without premeditation take on a strategic problem and, eventually, overcome it.

The dwelling view and the notion of practical coping are particularly useful to understanding strategizing activities that are not articulated through an explicit, formalized strategy (Chia \& Rasche, 2010; Hydle, 2015). However, there is a lack of knowledge about the role of accounting when actors strategize to practically cope with a problem at hand. Our paper addresses this gap. The study's focus is not in corporate meetings where actors are prone to strategize deductively, but instead on the everyday practical activities of actors who operate in a more localised, yet pluralistic setting and are prone to strategize in an inductive and explorative manner (Regnér, 2003).

\section{Strategizing agency}

Strategizing research asserts that actors who carry strategic agency are not limited to the upper hierarchical levels of an organization. Strategy work has been characterized as performative in nature and entangled with practices of power (Carter et al., 2010). Research on strategizing in pluralistic organizations emphasizes that diffuse power is held at multiple levels and by actors with different knowledges bases (Denis et al., 2007; Jarzabkowski \& Fenton, 2006). Strategizing studies have also explored the identity of strategists and have increasingly focused on middle managers or even frontline employees (e.g. Balogun et al., 2015; Lê \& Jarzabkowski, 2015; Mantere, 2005; Regnér, 2003; Rouleau, 2005; Rouleau \& Balogun, 2011). Other studies have investigated the dynamics between multiple hierarchical levels in organizations (e.g. Hoon, 2007; Mantere, 2008), and scholars suggest that strategizing agency is highly distributed, not only among actors across various organizational levels (Mantere, 2005; Vaara \& Whittington, 2012), but also across time and space (Hydle, 2015).

A discussion of strategizing agency, however, should not focus solely on explorations of who is considered a strategist. Carter et al. (2008) prompt researchers to shift their focus away from identifying trends and qualities of strategies and strategists, to explore the discourses, tools and rituals that people engage within their practice, which enable them, eventually, to be deemed as strategists. Maclntosh and Beech (2011) argue that the identity of a strategist is inherently complex and not easily identifiable, since the attributes of a strategist's identity are usually defined through dialogue and can be contextually unique in each social setting.

Indeed, Chia and Mackay (2007, p. 219) accord primacy to practices themselves as the locus of strategizing through their term of "practice-complexes". Boedker (2010) argues that strategizing agency is dispersed among both human and non-human actors, who collectively engage in intricate networks of strategic practice. She adds that non-human actors, such as material artefacts, often inform human agents' strategizing and may lead to strategizing outcomes that are difficult to predict, thus engendering a level of serendipity. Similarly, Tsoukas (2010) suggests that agency is embedded in sociomaterial practices, arguing that agents practically cope with emerging problems through spontaneous and non-deliberate engagement with their immediate sociomaterial environment. 
In light of the above, we theorize that accounting can be constitutive of strategizing agency, be it in the form of accounting artefacts and tools, systems or accounting practices. For example, Skærbæk and Tryggestad (2010) suggest that accounting and calculative devices (such as cashflow scenarios and SWOT analyses) have the power to incite and inform the strategizing of lay people who act as "accountants in the wild". Whittle and Mueller (2010) highlight the political power that accounting instils in organizational actors, enabling them to employ political tactics to work with, without, around and even against accounting. On the contrary, Denis et al. (2006) studied the power of numbers in strategizing and argued that, in pluralistic organizations, prolonged reliance on numbers may eventually lead to mechanistic decision-making, thus depriving agency from actors and assigning it to numbers themselves. We adopt a view of accounting and strategizing as contingent, practical activities (Chua, 2007) to explore the unpredictable ways in which accounting affects our actors' strategizing agency.

\section{Strategizing in episodes and stages}

Vaara and Whittington (2012) argue that little is known about how, when strategizing, practitioners learn to best navigate socio-economic practices. Some authors have explored strategizing as patterns which exhibit episodic unfolding through identifiable stages, conceptualizing strategizing as an intermittent process (Maitlis \& Lawrence, 2003; Jacobs \& Heracleous, 2007; Aggerholm et al., 2012). Others have researched strategizing through accounting practices as a continuous process which can enable (or sometimes impede) organizational members to progress strategically in dynamic, uncertain and complex environments (Jørgensen \& Messner, 2010; Denis et al., 2006; Cuganesan et al., 2012; Skærbæk \& Tryggestad, 2010).

According to Maitlis and Lawrence (2003), a strategizing episode is a series of distinct political and discursive stages where actors engage with a strategic issue, conceptualize potential solutions, assign responsibility and finally construct the strategic object (e.g. a strategic framework or a plan). Jacobs and Heracleous (2007) argue that strategizing through stages enhances actors' sensemaking of strategic issues. Hendry and Seidl (2003) employ Luhmann's (1990; 1995) notion of episode as a structured sequence with a beginning, a middle and an ending, arguing that informal episodes enable actors to disrupt routine organizational structures and engage in reflexive strategizing.

A view of strategizing as episodic, yet convoluted and unpredictable, allows us to theorize how strategizing begins, unfolds, where it possibly ends, and what role accounting plays in this pathway. Chia and Rasche (2010) suggest that actors are often so immersed in their highly intricate social settings that they instinctively and reflexively strategize when a problem suddenly appears. They add that strategizing agents engage in 'wayfinding' (Hutchins, 1995) to construct new 'action pathways' to elude their contextual, socially situated problems. Chia and Mackay (2007) suggest that strategizing becomes purposeful when actors fail in successfully negotiating daily tasks, which in turn leads them to reflect on their strategizing practice.

Strategizing, the enactment of strategy, is "work-in-progress" concocted though elaborate interactions between actors and recurring adjustments to a course of action (Ezzamel \& Willmott, 2010, p. 77). The "work-in-progress" metaphor emphasises that although actors who strategize may be inclined towards certain actions, for example, Clinical Directors may wish to boost the profitability of their Directorates, the enactment of strategy to achieve this occurs during everyday practices. Throughout the duration of a strategizing episode, actors debate and adjust 
their actions through adapting and responding to others' critique, in an attempt to facilitate consensus - whenever that is necessary for progression (Hall, 2017). Another take on strategizing as 'doing' is that, sometimes, a strategic objective may be cited as a rationale for engaging in a preferred action even if this action is not actually integral to the stated goal (Jørgensen \& Messner, 2010).

The lived experience of strategizing is messy, ambiguous and uncertain, challenging the orthodoxy of strategy which "tells you 'where you're going to end up"' (Samra-Fredericks, 2003, p. 142). In a milieu where strategizing is doing rather than telling, actors are not always cognisant of what others are doing or of the consequences of their actions, interactions and negotiations. Such circumstances highlight the uncertain nature of where strategizing "ends up". Moreover, whenever contentious issues are involved in a pluralistic environment, as in resource allocation within hospitals, it is easier and can be more expedient to act strategically, within strategizing, rather than discuss or document explicit strategy (cf. Brunsson, 1989; 1993). We turn next to the pluralistic setting within NHS hospitals.

\section{Research background}

Traditionally, NHS hospitals in England operated with global budgets and limited accounting and costing systems. While the activities and resource allocation decisions of clinicians were central to financial performance, most clinicians were unaware of and uninterested in such financial consequences. As constraints on resources became more apparent in the 1970s and 1980s, governments introduced policies designed to promote more active clinical resource management (Webb \& Wistow, 1982). But when clinicians strategized for resources, they favoured their own Directorates over others, and often saw overspending as an indicator of the need for more funding rather than a cause of concern (cf. Brunsson, 2000).

In the early 1990s, the government introduced Clinical Directorates; the intention was to engage clinicians with management and accounting practices (Kirkpatrick et al., 2012). Senior clinicians were appointed as Clinical Directors, they made financial decisions within their Clinical Directorates and had the power to manage them as semi-independent and self-directed units, thus increasing their financial responsibility and cost awareness (Ezzamel \& Willmott, 1993; Llewellyn, 2001; Nyland \& Pettersen, 2004).

Thus by 2003, when Payment by Results (PbR) was launched Clinical Directors were already more financially literate. $\mathrm{PbR}$ is a funding system which reimburses hospitals on the basis of the activity they undertake, using national average treatment costs to set tariffs for reimbursement (Department of Health, 2002). Tariff prices are linked with Healthcare Resource Groups (HRGs), which are groups of services that are clinically similar and require similar resources to deliver. Under PbR, hospitals have incentives for increased cost-efficiency, since, if they provide the required standard of care at a lower cost than the national average, they may retain any funding surplus (Street \& Maynard, 2007).

In light of PbR, Monitor ${ }^{1}$, the sector regulator for healthcare services in England, developed profit centres in hospitals through introducing Service Line Reporting (SLR), a new reporting tool that

\footnotetext{
${ }^{1}$ In April 2016, Monitor became part of NHS Improvement, an organization which regulates and supports providers and local health systems.
} 
measured the profitability of a hospital's 'service lines'. A service line is, broadly, equivalent to a medical specialty or hospital support service and is defined as "the natural "business unit" of the hospital- a distinct unit with identifiable customers, products, revenues and costs that is run as an independent business with its own income and expenditure" (Monitor, 2006, p.1).

Creating service lines as profit centres impacts on Clinical Directors' strategizing. Financial success for a service line rests on maximising its income and/or minimising its costs. Clinical Directors can mobilise service line performance as evidence, for example, for contesting allocated overhead costs and for rational investments in their specialties. Of specific interest is how service line performance steers Clinical Directors' strategizing as they cope with emerging problems which relate to the profitability of their service lines.

\section{Methodology}

The empirical data for this paper was gathered as part of a larger research project, funded by the National Institute for Health Research. We investigated how Clinical Directors used accounting at four case studies of English NHS hospitals. This paper draws on qualitative data from three of these case studies, anonymized as Alpha, Beta and Gamma.

\section{Research design and data collection}

The study employed an inductive, multiple case study design to elicit meaningful and robust data in relation to our research question (Yin, 2003). A multiple case study approach was selected for replication and theory development purposes (Scapens, 2004). Case study research is valuable for investigating management accounting (Scapens, 1990; Cooper \& Morgan, 2008) and strategizing practices (Vaara \& Whittington, 2012), due to its context-sensitivity in exploring actual, everyday practices and organizational phenomena.

Clinical Directors' strategizing with accounting depends, at least in part, on their competence and engagement with accounting. The four case study sites were identified and selected for their high level of clinical engagement with the Finance function". Our four sites "epitomize a broader category of cases" (Bryman, 2016, p. 62) since 56\% of all NHS hospitals display similar high engagement levels (Department of Health, 2016). A replication logic was employed in all cases to convey either similar or contrasting analytic results (Yin, 2003; Eisenhardt, 1989).

Data collection involved semi-structured interviews and documentary analysis. A total of 38 interviews were conducted at the four case study sites from February 2013 to May 2015. Specifically, we interviewed 24 Clinical Directors, 2 Medical Directors, 4 senior consultants, 2 Finance Directors, 9 Business Managers (located at the directorate level) and 2 Chief Executives. The interviews included six interactive discussion group interviews with Clinical Directors and their Business Managers to accurately capture the clinical and financial insight of the study's participants simultaneously. Interactive discussion groups are a methodological approach to better understand strategizing, since it enables the researcher to explore the "collectively shared knowledge beyond the top management team" (Balogun et al., 2003, p. 203). To develop the

\footnotetext{
${ }^{2}$ All four case study sites reported joined-up, collaborative work at the highest level (i.e level 4) between clinicians and finance staff in an annual Department of Health costing survey.
} 
narratives for this paper we identified 10 participants whose joint experiences constituted three extended episodes.

Consistent with the focus of our study, our questions, at interview, broadly explored the role of accounting in our interviewees' strategizing to ensure the profitability and development of their services. All interviews were recorded, except for one where recording permission was denied and notes were taken instead. Recordings were transcribed verbatim, producing 625 pages of transcripts. The average duration of each interview was approximately 60-75 minutes.

Documents were also collected, such as business cases and business case templates, financial reports, strategy documents, minutes from Board meetings, staff training presentations and conference presentations.

A list of the interviews and documents pertaining to each of the cases described in this paper are included in the appendix.

\section{Data analysis and theorization}

First, the interview transcripts were grouped per case study site, the names of the interviewees were anonymized and all transcripts were imported to the qualitative analysis software NVivo for classification purposes. Then, all transcripts were manually coded into emergent themes to form a draft theme-code template. We exhausted all interview transcripts from a single case study to obtain a general understanding of the depth and meaning of the interviews' content and the case study sites' context before proceeding to the next site. A second round of analysis focused on the themes we identified. Different themes that shared the same context or exhibited a similar meaning were grouped together. Throughout this process, NVivo assisted in manually generating codes, on the segmentation of text and in describing, labelling and grouping together different themes.

At this point, the collected documents and secondary data were reviewed and 'winnowed' (Guest et al., 2011). Document analysis took place after the interview themes were produced, since interviewees shared most of the collected documents directly with the researchers after the interview was conducted, to complement the various topics that were discussed. Thus, we identified the documents and secondary data that directly relate to our narratives, either by extending the context of the discussion or by providing illustrations.

Consistent with our inductive, multiple case study design, we theorised our empirical data via "recursive cycling among the case data, emerging theory, and later, extant literature" (Eisenhardt \& Graebner, 2007, p. 25). This approach enabled us to refine our research question and theoretically explain our findings over time. We embarked on data collection with a broad theoretical understanding of strategy and strategizing. This was finessed as we engaged with accounting and strategizing literature throughout the data collection and at the data analysis stages. As the second round of analysis concluded, we focussed specifically on the Jarzabkowski et al. (2007, p. 7-8) strategizing definition: "strategizing comprises those actions, interactions and negotiations of multiple actors and the situated practices that they draw upon in accomplishing that activity". This definition assisted in identifying strategizing behaviour in our data but offered little to differentiate strategizing which embeds strategic intent from that which remains at the level of practical coping. In consequence, when we identified activities, we searched for the strategic intent in our actors' behaviour along with any shifts in their strategic direction. 
We present our findings in the form of three strategizing narratives (Llewellyn, 1999; Czarniawska, 2004; see also, Llewellyn, 2001; Jørgensen \& Messner, 2010). Narratives demonstrate how strategizing invokes action and how action culminates in organizational events (Llewellyn, 1999). Similar to Llewellyn (2001), our strategizing narratives express Clinical Directors' concerns and contemplations on 'how to proceed' to action. In writing our narratives, we follow the 'emplotment' suggestions of Czarniawska (2004, p.122) on how to structure narratives to make sense of reported events. Thus, the selection of our narratives was based on the adoption of selected theories (ibid, 2004).

Our focus is on Clinical Directors as agents who enact their own strategies within the world they inhabit (Chia \& Holt, 2006; Ezzamel \& Willmott, 2008). We employed the notion of a strategizing episode (Hendry \& Seidl, 2003; Jarzabkowski \& Seidl, 2008) to select examples of strategizing and indicate how strategizing is constructed and performed within an identifiable beginning and ending. To identify the starting point of a strategizing episode, we engaged with the notion that actors strategize when facing a problem or a crucial issue in their practice environment (Chia \& Holt, 2006; Chia \& Rasche, 2010; Tsoukas, 2010). We then discerned the strategizing activities that emerged from practical coping, enabling us to pinpoint the adaptive and episodic nature of our identified strategizing examples. Our strategizing episodes end when actors' strategizing is fully realized, with discernible effects within their locales, and, sometimes, organizations. Such theory-driven analysis led to the development of our three strategizing narratives.

\section{Clinical Directors' strategizing with accounting in English hospitals}

This section presents three narratives which explore how accounting is implicated in the unfolding of strategizing.

\section{Strategizing narrative 1: Contesting bad debt}

Here, we focus on the Clinical Director of Women's Services at Alpha. Her role was twofold: first, she had responsibility for her Directorate's financial performance; second, as the Deputy Medical Director, she was a senior leader for the hospital as a whole. Her concern was the bad debt charges allocated to her service.

At the time of our narrative, the Clinical Director had indicated an interest in participating in a 'deep dive' review of her Directorate's financial position. These reviews are mainly targeted at loss-making Directorates but to mitigate conflict they began in Directorates like Women's Services which were open to an investigation of their costs and income. The Deputy Director of Finance commented:

"So I was talking about the deep dives... I've got three specialties on the go now.... And I've had an email this afternoon that Women's Services want to jump in as well." [F1-A]

In the event, the Director of Operations, who was in charge of the deep dive process, said:

"So I remember a conversation with the Women's directorate. We were looking with them at [their] top ten most loss-making HRGs, the most loss-making HRG was patients that didn't have any complications... so we were trying to unpick why would it be so very loss-making." [OD-A] 
Participating in this deep dive, would have focussed the Clinical Director's mind on areas of her Directorate which lost money. As such, overseas patients presented as a particular problem.

\section{The problem which prompted strategizing}

Women's Services at Alpha provide maternity care and gynaecological services. The Department of Health deems maternity care as 'immediately necessary', since the denial of care or any delay in providing treatment can affect the health of both mother and unborn child, therefore hospital regulation dictates maternity treatment should be immediately provided (Department of Health, 2010). This reflects NHS founding principles: care must meet the needs of everyone, be free at the point of delivery and based on clinical need and not the ability to pay.

As a result Alpha was owed more than $£ 5.5$ million from overseas patients for unpaid bills in 2015/2016 - the highest debt owed to any UK hospital. Foreign visitors may receive but are not entitled to free NHS treatment. Hospital services ${ }^{3}$ provided to overseas patients are chargeable and hospitals have the authority to chase such debt. The treatment of patients who are not eligible for NHS care leads the Directorate of Women's Services to be confronted with a substantial overhead charge for bad debt recovery.

"... [P]art of the overheads is the cost for bad debt... when patients don't pay for their care, non-NHS patients." [CD-A]

In addition, if the bad debt is not recovered, the Directorate owns it.

"We had a particular issue around... chasing the bad debt from those women... [Otherwise] we - the Directorate owns the bad debt." [CD-A]

The NHS acknowledges the difficulty in determining and recovering this debt. Hospitals run central administrative services that try to recover bad debt from overseas patients, but the Clinical Director is emphatic that central administrative services do not perform well. Hence, the Directorate's income and overall financial performance is partially reliant to how effective central services are in debt recovery.

"...[T]he people who chase the debts are employed centrally... we pay someone else to chase that for us through overheads. But we have no influence over how well that's done. [But] they [central administration] are a very key part of our performance" [CD-A]

Having constructed the problem, the Clinical Director made her first strategizing attempt. Throughout the episode her agency was paramount. As a senior manager she had considerable power within her Directorate but, in the pluralistic environment of a hospital, to effect change much depends on other key actors.

\section{Practical coping: strategizing for a rebate}

As an accounting issue, the Clinical Director raised the unsuccessful recovery of bad debt with Finance. She challenged the effectiveness of central administration, pressing Finance to recognise an inadequate performance.

\footnotetext{
${ }^{3}$ This excludes Accident \& Emergency (A\&E) services and walk-in centres.
} 
"So we've said to [Finance], "Well hang on a minute, why should we pay you to unsuccessfully chase the debt... we don't think you're doing the chasing well enough so why should we pay you for that out of the overheads?" [CD-A]

Finance did not acknowledge the shortcomings of central administration but the Clinical Director continued to lobby and practically coped with the problem by trying to negotiate a rebate.

"Every so often we might say to [the Finance Director], this is how much you're charging us, you know. How are you doing what you do [chasing bad debt] more efficiently out of the overheads and if you aren't, can we have a rebate?" [CD-A]

The Clinical Director then took this one step further through confronting the Finance Director in a formal performance meeting. She verbally challenged the efficiency of the bad debt collection service in front of the others present.

“...[T]he Director of Finance was actually at the [Directorate's monthly performance review] meeting, so we were able to talk directly to the Director of Finance saying, "Yes, we have got that bad debt but actually we are not the people responsible for collecting it, we pay you to do that effectively."'" [CD-A]

But these recurrent conversations with the Finance Director, even in a formal setting and in front of others, were unsuccessful in achieving a rebate. At this point the Clinical Director adapted her strategizing; this new iteration took on a more explicit strategic intent.

\section{Strategic intent: Strategizing to chase the bad debt from within Women's Services}

The Clinical Director pushed Finance to agree to the Directorate being responsible for recovering bad debt. As a profit centre, formally, Women's Services should have the autonomy to make this choice. Strategic intent was evident because her proposal to chase bad debt from within her Directorate was proactive in recommending a long term change involving a reassignment of responsibilities and accountabilities, accompanied by a reallocation of resources from central administration to Women's Services.

"So there, one of the options is to challenge [the bad debt recovery service] and say, "Right, we will chase our own bad debt, so take that out of our overheads, because we don't want to subscribe to your service anymore, and give us that money and we will chase the bad debts for ourselves."'” [CD-A]

She predicted that Women's Services would outperform the centralized service in chasing bad debt resulting in a better financial position for the Directorate over the longer term.

"I would expect the overhead cost to go down... And I would hope that because we were doing it better we might see (laughs) that we were performing better against our bad debt provision, so there'd be less variance... So ideally this is a long-term thing so you don't have to plan for so much bad debt because you're better at collecting it." [CD-A]

Unfortunately for the Clinical Director, her negotiation with Finance was not fruitful. Maitlis and Lawrence (2003, p. 130) argue that "an episode of strategizing will be more likely to fail when organizational politics do not allow for the assignment of responsibility and accountability in a way that benefits key actors". Clearly, if Women's Services took on their own bad debt recovery this may impact on the viability of central support services. Furthermore, other Directorates 
could follow suit in taking other central support services in-house. In any event, the Clinical Director failed in her strategic intent to run debt recovery from within her Directorate. Finance continued to support a centrally provided bad debt recovery service for all Directorates.

"...[Finance] retained the bad debt chasing centrally, it wasn't allowed to come out to Women's Services..." [CD-A]

After this setback the Clinical Director dropped her strategy to take on debt recovery and returned to practical coping. This time, her strategizing efforts focussed on the process of checking on eligibility for free care rather than requesting a rebate.

\section{Reverting back to practical coping: Strategizing to address bad debt earlier}

This new iteration of strategizing over bad debt recovery looked upstream for a solution. Llewellyn (1999, p. 223) argues that strategizing is both a forward looking method of "starting to achieve what we want" and a backward looking method of contemplating potential outcomes of different configurations of past scenarios. Since Women's Services cannot deny treatment to patients who are not eligible for free care, and as the bad debt recovery remained with the designated central administrative service, the Clinical Director sought to solve the problem at its source: by checking earlier on non-eligibility and deterring any patients not entitled to free care.

"...[W]e invested from within our funds in ways of trying to check quite early on if women were eligible for care... [W] can't not treat them but... having the conversation [with non-eligible patients] early on that says, "Actually, you're not eligible for NHS care, you're quite welcome to continue with your care but you will receive a bill."... It's a deterrent to people who are abusing the system..." [CD-A]

Since most maternity services which result in bad debt relate to the costs of delivering the baby and the consequent neonatal care, the Clinical Director addressed the problem through strengthening eligibility checks at antenatal appointments and signalling earlier billing.

"... [W] sort of have to work around [the bad debt] by trying to not let people generate the bad debt in the first place." [CD-A]

In this case, the Clinical Director initially drew on her knowledge of organizational rules and accounting processes of how bad debt is formulated and chased. In her pursuit of alleviating the financial consequences of the unsuccessful central chasing and allocated overheads on her service, she effectively changed the process to one whereby her Directorate identifies overseas patients. Ironically, this boosted central services' success rate in recovering the bad debt.

"I think it's probably fair to say we did get a step up in performance... [W] over performed on [overseas income], and that's partly a reflection of us making more effort to get people to actually pay us." [CD-A]

The following table illustrates an anonymized excerpt of the directorate's monthly performance review, indicating the costs for bad debt provision and overseas income. The table shows that in February 2014, Women's Services' overseas income had a $£ 579 \mathrm{k}$ favourable Year-To-Date (YTD) variance, a figure that was projected to reach $f 615 \mathrm{k}$ at the end of the financial year.

Table 5.1: Women's Services monthly performance review 


\begin{tabular}{|c|c|c|c|c|}
\hline \multicolumn{4}{|l|}{ Women's Services } & \multirow{2}{*}{$\begin{array}{l}\text { Feb-14 } \\
\text { Projected } \\
\text { Year End } \\
\text { Variance }\end{array}$} \\
\hline Key Variances & $\begin{array}{l}\text { Annual } \\
\text { Plan }\end{array}$ & $\begin{array}{l}\text { YTD } \\
\text { Plan }\end{array}$ & $\begin{array}{l}\text { YTD } \\
\text { Variance }\end{array}$ & \\
\hline \multicolumn{5}{|l|}{... } \\
\hline Overseas Income & (390) & (357) & 579 & 615 \\
\hline \multicolumn{5}{|l|}{$\ldots$} \\
\hline Bad Debt Provision & 476 & 436 & (206) & (238) \\
\hline$\ldots$ & & & & \\
\hline \multicolumn{5}{|c|}{$\begin{array}{l}\text { Key YTD Expenditure Variances: } \\
\text { Overseas Income } f 579 k \text { fav. } \\
\text { Overseas patient delivery income, though this is largely offset by the level } \\
\text { of bad debt provided. } \\
\ldots \\
\text { Bad Debt Provision } f(\mathbf{2 0 6}) \text { adv } \\
\text { Overseas Maternity Income } f(403) \text { adv. With additional } 100 \% \text { provision for } \\
\text { antenatal pathway transfers of } £ 60 k \ldots\end{array}$} \\
\hline
\end{tabular}

Source: Monthly Women's Services performance review, February 2014

The Clinical Director explained this favourable variance as due to an assumption in the annual budgeting calculations that the specialty would not receive any overseas income.

"...[A]t the beginning of the year we pretty well assume we're not going to get any of that [overseas income] paid, so we reflect it in our bad debt provision... [Also] we were hoping to have not as many overseas women coming through. So it's not an income line we like to promote, unlike all the other income lines, because we automatically assume it exists but we won't receive the money." [CD-A]

This assumption led the Clinical Director and her team to postulate an adverse variance on overseas income and to inflate the bad debt provision when devising the annual budget at the beginning of the financial year.

"So where they've said a hundred percent provision for antenatal pathway transfers... they're expecting sixty $K$ of money..., so they've made a hundred percent provision for that in the bad debt position..." [CD-A]

At the time of our interviews this concluded the strategizing episode. Despite her set-backs, the Clinical Director reflected on the challenge to Finance itself as a success - in bringing her recognition among her peers and arousing their interest, enabling peers to see the possibilities inherent in negotiating accounting practices.

"I think we got recognition for doing it, but I don't think we changed the system. We set people thinking about it... I think the fact that a challenge was made was a success actually... I think [the Finance Director] was really quite surprised to have [bad debt] pushed back." [CD-A] 


\section{The stages in the episode}

After engagement with Finance in a deep dive review which highlighted areas of her specialty which were loss-making, the Clinical Director focused on overseas income. Following an initial construction of the problem over overseas income, this strategizing episode played out over three stages. At Stage 1, the Clinical Director disputed her Directorate's allocated overhead costs for chasing bad debt and lobbied against the central administrative services pursuing it, challenged their effectiveness and negotiated for a rebate, however this was unsuccessful. Nevertheless, the Clinical Director was not deterred. At Stage 2, she negotiated against subscribing to the centralized services and strategized towards taking on bad debt recovery herself. But this too failed. She then reverted to another practical coping modus operandi at Stage 3. She identified potential non-payers earlier in the care process to try to deter them from defaulting. Paradoxically, this early intervention from within Women's Services would have rendered central administration's task of bad debt recovery easier - their performance may appear to have improved as a result.

The episode was one of wayfinding, where impasses prompted the taking of different paths and uncertainties remain. Negotiating for a rebate was unsuccessful. The strategy to take debt recovery into the Directorate failed. Checking earlier on eligibility seemed a partial success but this could be characterised as taking on some of the work of central administration without any compensating resources. The narrative ended in some doubt over whether the bad debt problem can yet be addressed to the greater satisfaction of the Clinical Director of Women's Services.

\section{Strategizing narrative 2: Conforming to capital investment rules}

This narrative focuses on the Clinical Director of Clinical Haematology at Beta, a tertiary hospital, which provides specialist cancer services. The Clinical Director heads a Haematology Transplant Unit (HTU) which treats blood related cancers in patients who need intensive chemotherapy and bone marrow transplants. Here, we highlight the Clinical Director's efforts to secure investment to relocate and merge the HTU with the Young Oncology Unit (YOU) into a new, purpose built facility to provide an integrated service.

\section{The problem which prompted strategizing}

Clinical Haematology was facing increasing demand for transplants and chemotherapy but inpatient facilities were outdated and provided only limited space. Finance was aware of the pressing nature of these issues, the Finance Manager commented:

"...[W]hat you'd got [in Clinical Haematology] is a ward that was in desperate need of updating, it was very, very old, very tired, and you also had a situation where Clinical Haematology [...] is actually growing, so there's actually a capacity issue there as well." [F2-B]

Naturally, the Clinical Director of Haematology was keen to secure investment in his service but there was a serious impediment - Haematology services had a combined annual loss of approximately $£ 3$ million. This, unsurprisingly, caused some disquiet and hesitancy in Finance over any possible investment in the specialty. The Finance Manager, again, commented:

"The thing is, when [Clinical Haematology] came to us in the first instance and said right, okay we want a new build, it was like right, okay, let's have a look at the service line. 
We're losing quite a lot of money... do you want to invest in a service line that's actually losing money?" [F2-B]

The Deputy Director of Finance, who, at the time of the interviews was Acting Director of Finance, added that for any business case for investment would have to meet a service line improvement criterion.

"I don't care where you work, there is always an efficiency question to answer... [Clinicians] know that every business case that's over, you know, a material [amount] needs to demonstrate service line improvement" [F1-B]

But aside from the financial hurdles, another issue in securing investment in the service were the past tensions between Haematology and Finance. Specifically, the Clinical Director was constantly being reprimanded by Finance for not meeting his financial targets. He bemoaned:

"... [H]istorically I suppose one of the things that used to frustrate me was being in our meetings [with Finance] and constantly being reminded about the fact that we were under performing, or at threat, or having to justify our existence." [CD-B]

The Clinical Director's first strategizing move to obtain investment in Haematology was to show more interest in his specialty's financial profile and, also, relatedly, improve his relationship with the Finance function.

\section{Practical coping: strategizing to acquire financial agency}

The Clinical Director reflected that rather than constantly fighting Finance, a better approach to practically cope with the problem would be to understand more about the financial side of "the business". The Clinical Director sought to acquire financial expertise to improve relationships with Finance.

"[I was] thinking, rather than fight... saying, finance are being a pain... alternatively... let's understand a bit more about what's going on here because we're grown-ups and it's business." [CD-B]

So he decided to interrogate the figures to grasp his specialty's financial strengths and weaknesses.

"Digging beneath the surface [asking] how is the work I do funded? It surprised me, the sort of naivety... there are two parts to our activity. One is stem cell transplantation... The other side was all of the non-transplant. So, the cancer, leukaemia, lymphoma work was loss leading. We knew we made a lot of money from one, we knew we lost money from the other [but] how much it really costs to deliver the treatment, nobody seemed to understand... So it was a real stifler to any kind of investment." [CD-B]

Around the time the Clinical Director was finding out about how his service was funded and which aspects of his clinical work were profitable, Finance were introducing PLICS (Patient-level Information and Costing Systems) and seeking to actively engage Clinical Directors in this new costing method. Through PLICS, Finance anticipated understanding costs better, but, perhaps more significantly, for very complex clinical care, for example, stem cell transplantation (see above quote), they hoped to influence the future national tariff at a time when the government 
were seeking PLICS data from specialist hospitals, like Beta, to help them set these new tariffs. The Clinical Director anticipated benefits to the hospital and his service from PLICS.

"And so that was when, Finance were looking at introducing PLICS... Saying we can be part of somebody else's costing model [or] we can pioneer... and actually set the tariff. It might be somewhat self-serving, but ultimately, if we get [the tariff] right for us, then who cares about how it works for everybody else?" [CD-B]

Moreover the Clinical Director needed to understand PLICS data because it was required in business cases. The Finance Manager pointed out:

"In all honesty, the way that it's worked best for us has been through business cases... we've got [clinical] engagement [in PLICS] through business cases." [F2-B]

This alliance of interests between the Clinical Director and Finance resulted in him actually working with Finance on PLICS and presenting, with the Deputy Director of Finance, to a professional health accounting association on their PLICS work.

“... [the Clinical Director for Haematology]'s one of our more engaged clinicians, ...he has been quite influential in some of the work that we've done... I've worked with [him] on developing tariffs... we've done a few presentations for the XYZ [anonymized acronym for the professional health accounting association] - I took [him] along, actually, to one of them." [F1-B]

The presentation to the XYZ explained how to use PLICS to benchmark costs against national tariffs. By this time, the Clinical Director had a jocular attitude towards Finance's previous view of Clinical Haematology. He used a slide showing two senior managers, dressed in suits, shovelling money into a hole, indicating that Finance had seen his specialty as a "black hole" where money was concerned. Recounting the Clinical Director's presentation, the Finance Manager commented:

"...[The Clinical Director]'s saying that's what [Beta] perceived the Clinical Haematology department to be... just literally - Money, black hole, which I thought was quite funny." [F2-B]

These comments from the Clinical Director and Finance demonstrated the shift between them towards a more congenial relationship. Additionally, the Finance Director was, of course, a key figure in developing and appraising the business cases which came to the Board of Directors, so securing an affable relationship with her could only have advanced the prospects for the Clinical Director's project.

\section{Strategic intent: The merger}

As mentioned above, in Beta there was a Young Oncology Unit (YOU). In July 2011, they submitted a proposal for the development of new YOU building, but the Board rejected it because it "required significant capital investment but did not meet all the requirements of the service users, nor did it deliver efficiencies" (Source: Detailed review of the development of an integrated YOU and HTU, p.2). However, the Board requested an updated business case that would take into consideration the potential benefits of a new, integrated facility between YOU and HTU for improving the financial performance of both service lines. Backing such a merger 
would be a strategic decision because capital investments are made on the basis of business objectives. The Chief Executive of the hospital explains how a financial target tested the ability to meet business objectives:

"The business case would only be approved if it met a financial test, which was an improvement of $15 \%$ on the service line..." [CE-B]

After the failure of the original YOU proposal, the Clinical Director of HTU picked up on the Board's suggestion of a merger between HTU and YOU. He was proactive in leading on the formulation of a business case to develop a new integrated facility at an estimated cost of $£ 13.5$ million which conformed to the financial test through projecting a combined YOU/HTU improvement of $30.5 \%$ income growth. This demonstrated strategic intent because the proposed merger was a strategic decision for the Board.

\section{Substantiating strategic intent through a business case to secure investment}

The updated case was submitted to the Board. It highlighted the loss-making nature of both units prior to the suggested merger, as displayed in the following table.

Table 5.2: Service Line Positions for the HTU and the YOU

\begin{tabular}{|l|l|l|l|l|}
\hline & \multicolumn{2}{|l|}{$2010-11$} & 2011-12 (Baseline) \\
\hline & YOU & HTU & YOU & HTU \\
\hline Tariff income & $2,064,063$ & $10,129,514$ & $2,603,369$ & $11,483,313$ \\
\hline Total cost & $4,177,971$ & $11,024,269$ & $4,287,128$ & $12,636,595$ \\
\hline Contribution & $-2,113,909$ & $-894,755$ & $-1,683,759$ & $-1,168,282$ \\
\hline $\begin{array}{l}\text { Total } \\
\text { Contribution }\end{array}$ & $-\mathbf{3 , 0 0 8 , 6 6 3}$ & & $-\mathbf{2 , 8 5 2 , 0 4 1}$ & \\
\hline
\end{tabular}

Source: Detailed review of the development of an integrated YOU and HTU, 2012

But the business case was optimistic in indicating that the merger would lead to staffing efficiencies, release of rent and would allow for mixed sex accommodation, leading to savings of f264k and an improvement of $30.5 \%$ over the YOU and HTU's combined service line position.

Table 5.3: Efficiencies identified

\begin{tabular}{|l|l|}
\hline & $\begin{array}{l}\text { Value } \\
f 000\end{array}$ \\
\hline Staffing Efficiency & -408 \\
\hline Estates Savings (release of rent) & -32 \\
\hline
\end{tabular}




\begin{tabular}{|l|l|} 
Sub Total & -441 \\
\hline Allowance for Mixed Sex Accommodation & 177 \\
\hline Total & -264 \\
\hline
\end{tabular}

Table 5.4: Improvement in service line position

\begin{tabular}{|l|l|}
\hline & $\begin{array}{l}\text { Value } \\
f 000\end{array}$ \\
\hline Combined service line position & -863 \\
\hline Efficiencies identified & 264 \\
\hline Revised service line position & -599 \\
\hline Service Line Reporting \% Improvement & $30.5 \%$ \\
\hline
\end{tabular}

Source: Detailed review of the development of an integrated YOU and HTU, 2012

The Clinical Director's strategizing was successful. The Board approved the merger, even though the investment would not lead to a profit-making specialty.

"So that business case was approved by the board on the understanding that - they weren't expecting them to get into a profit situation, if you like, but what they wanted to see was a better contribution going forward, to overheads..." [F2-B]

The Clinical Director sounded rather surprised that Finance had confidence in his optimistic plan for income growth.

"[Finance] believe[s] ...that that increase in growth will generate income, and it gets supported with capital spend." [CD-B]

As mentioned earlier, this business case was the second proposal to the Board and involved the staff of two substantial units. According to Spee and Jarzabkowski (2011), a strategic document increases its authority through multiple iterations of amendments and the extended involvement of multiple actors.

"It has now been approved, and [the integrated unit]'s being built and will be open in March, so that's the end point of, I suppose, a success story." [F1-B]

Notably, despite investing in a loss-making service, both Finance and the Clinical Director agreed that creating the new facility was beneficial.

\section{Reflecting on being a financial agent}

The HTU Clinical Director's efforts also had indirect results. The process of collaborating with finance managers, formulating the proposal which conformed to accounting rules and eventually 
achieving the investment, resulted in a change of how Finance perceives Haematology. He comments:

"And now we are, as a department, viewed very favourably and it takes the heat off and it's made it much easier to work. And I think that it's not just working with Finance, but how we're viewed by the [hospital] executive is very different... than it was before we did this work." [CD-B]

In addition, he believes that the granting of the business case legitimized further investment. At the time that interviews were taking place, a new outpatient facility was being developed, due to the specialty being able to undertake further activity. The business case positioned the service line as more financially sustainable. In this new situation, undertaking more activity makes financial sense. Hence, the Clinical Director was convinced it was easier for Beta to grant further investment for a new outpatient facility in addition to the new ward.

“... [N]ow we've got a new ward and we're also in advanced stages to get a new outpatient facility... And that then acts as a driver to expansion through increased activity because it's scalable. Saying, okay, you know that you do 100 cases a year and you'll make this much money. So, brilliant, go and do 120 and then we can make even more. And if you need the investment to be doing that, then [Finance]'ll support it..." [CD-B]

\section{The stages in the episode}

This episode took three stages for the Clinical Director to secure a successful outcome for his business case. At a fourth stage, Finance demonstrated an on-going commitment to his service. At the first stage, once the problem was defined the Clinical Director took steps to forge a congenial relationship with Finance through assuming financially-driven agency. As such he became an ad hoc member of the Finance team through presenting with them at accounting events. This positioning conferred strategic advantage when he submitted his business case. We characterize this submission, at Stage 2, as having strategic intent because business cases from profit centres are used as leverage to legitimize capital investments and persuade an audience. The narrative had a distinct, successful ending when, at Stage 3, the Clinical Director secured investment for an integrated HTU/YOU unit through putting forward figures which conformed to the imposed target for income growth.

Finally, the Clinical Director reflected on the considerable benefits of working with Finance rather than railing against them, indicating optimism about further investment into the future. Contrary to the first episode, the Clinical Director's strategizing displayed synergy, discipline and compliance - characteristics which accentuate the conforming mode of engaging with accounting.

\section{Strategizing narrative 3: Circumventing transfer price charges}

Here, we focus on the Clinical Director for Surgical Neurosciences at Gamma, a hospital which offers acute and community care services. This narrative concerns the Clinical Director's dismay at the high transfer price theatres were charging for his pain management patients and his subsequent bid for the development of a new facility, the 'Pain injection centre'. His specialty as a whole was already profitable and fared well with Finance but pain injections lost money because of the high transfer price charged by theatres.

\section{The problem which prompted the strategizing}


The impetus for the 'Pain injection centre' business case was the realization that pain management was financially problematic for the service line. The Clinical Director explained how he came to realise that their routine pain injections lost money because theatres were charging a high transfer price for time/space to cover their high cost activities.

"...[T]his is an injection that takes ten minutes. You come into a sterile area, you have a needle stuck in your back and then you go home. So the HRG for an injection is something like... eight hundred". We found we were losing money on these and you're thinking, "The fixed costs are the staff; they're already there. The recurrent expenditure is a syringe and a needle. We're charging eight hundred quid and we can do ten of these in a [theatre] session. How can this lose money?" Well the answer is that the theatre was charging a fixed price per minute to cover all the costs including the high cost areas like hip replacement." [CD1-G]

Here, the Clinical Director was initially unaware of the high theatre transfer charge, so "losing money" was a puzzle. In essence, for their pain injection activity, they were dwelling in a highcost theatre facility. This generated impromptu strategizing on how to practically cope with this loss-making service within a profitable specialty.

\section{Practical coping: Strategizing over the theatre transfer price}

The Clinical Director and his Business Manager were aware of the high cost of theatres. The Business Manager commented:

"... [I] [the pain injection]'s done in theatre you have a higher level of overhead. You've got the theatre team, you've got the overheads of running that." [BM-G]

Furthermore, the Clinical Director for theatres at Gamma points to theatre utilisation and flow (or throughput) as the only way that theatres can make money to offset their costs and the removal of the pain injection patients may reduce utilisation.

"It's the flow into theatre that needs to be corrected, and it's the utilisation. That's the only way you can make money. If you're not operating, you're not making money. So I'm sounding a mercenary, but that is the reality of it. You know, it's $f 12$ a minute; there are ten theatres down there, it's a huge amount of money." [CD2-G]

The Clinical Director for Surgical Neurosciences, however, was not concerned with theatre costs and utilization. His focus was on the "crude" nature of theatre transfer pricing, highlighting that the same charge per minute was made for all procedures and applied across all the theatres. In consequence, there was no designated theatre for less complex, lower cost procedures. Effectively theatres were cross-subsidizing their high cost, complex cases, for example, hip replacement, against their lower cost, standardized cases, like pain injections.

"In this hospital you've got fifteen, twenty theatres doing a whole range of procedures and producing from that an average cost per minute irrespective of what the procedure is. So... the charging side of it, is still very crude." [CD1-G]

\footnotetext{
${ }^{4}$ The Clinical Director was mistaken about a tariff of $£ 800$. The tariff was $£ 602$ and this was the actual figure that was included in the formal calculations of income for pain injection patients.
} 
As the buyer of the service, if the Clinical Director had followed the "textbook" accounting approach, he would have tried to negotiate a new transfer price. Theatres, as sellers, are dependent on their hospital service lines for "business" because they cannot trade in an external market. Moreover, their profit centre status, allied with their dependence on utilization, should render them willing to negotiate. Nevertheless, the Clinical Director circumvented any, potentially, difficult negotiations with theatres over transfer pricing. He took an entirely different route.

\section{Strategic intent: Strategizing for a new facility}

Instead of challenging the theatre transfer price, where a successful negotiation would not have incurred any extra costs for the hospital as a whole, the Clinical Director strategized for a new build bespoke facility - the pain injection centre. There was no suggestion that the current theatre facilities required updating or were unsuitable for the pain injections patients. The Clinical Director took the opportunity to act strategically and proactively to secure a new facility, which would involve a considerable allocation of additional resources to his Directorate. He explained the strategic intent behind this.

"So, by taking out and creating an injection centre, the costs were just the costs of the injection centre, rather than the whole of theatre costs." [CD1-G]

Furthermore, the Business Manager claimed that relocating pain injection patients to a new facility would enhance flow, as well as avoid theatre overheads.

"[Patients]'d have been picking up expensive theatre overheads when really they were just a person in there for fifteen minutes getting their injections... It's not best use of a theatre environment... Obviously these patients don't need to [go] into recovery, but there was an element of it affecting the flow through theatres... Well, we can do it through an injection centre." [BM-G]

The development of the dedicated pain injection facility would require significant capital investment. In contrast, it should have been possible to negotiate a new transfer price at no cost for the hospital as a whole. But, surprisingly, the Clinical Director was optimistic that funds would be granted since Finance had a generally favourable stance towards the Directorate's initiatives in generating more income.

"It is known that our division [...] makes money... So there is a great desire to facilitate us doing our financial job as in making money, so if there is a need for more theatres... that will be looked on favourably..." [CD1-G]

\section{Substantiating strategic intent with patient-level costs}

As at Beta, capital investments at Gamma are typically granted though business cases. The Business Manager explained that an awareness of overheads and staffing costs led to the formulation of a business case for a new pain injection centre.

"...[S]o we were able to present a case for an injection centre. So [patients] effectively go into an injection centre - less overheads, less staffing there." [BM-G]

To make the business case for a new facility the Clinical Director and his Business Manager had to demonstrate that the investment would save money for the specialty - as compared to 
undertaking the cases in theatre. There was no requirement, however, to assess the financial impact on the hospital as a whole.

A pain injection is a straightforward procedure which does not depend, to any great extent, on the physical condition of the patient. In the above quotes, the Clinical Director and the Business Manager claim that the injection itself only takes 10-15 minutes. A sample patient episode cost $(£ 1,070)$ for the high cost theatre is given below. This represents the total cost attached to this patient from admission to discharge, as reported by the hospital's patient-level costing system. Clearly, this cost was, indeed, higher than the HRG tariff of $£ 602$. In consequence, the loss on this patient would have been $£ 468$.

Table 5.5: Episode cost for an individual patient in the high cost theatre

\begin{tabular}{|c|c|c|c|c|c|c|c|}
\hline \multicolumn{5}{|c|}{ Episode: Key Stats \& Costs for patient XX } & \multirow[b]{2}{*}{$\begin{array}{l}\text { \# Theatre } \\
\text { Mins }\end{array}$} & \multirow[b]{2}{*}{$\begin{array}{l}\text { \# Theatre } \\
\text { Visits }\end{array}$} & \multirow[b]{2}{*}{$\begin{array}{l}\text { Theatre } \\
\text { Cost }\end{array}$} \\
\hline Period & $\begin{array}{l}\text { Point of } \\
\text { Delivery }\end{array}$ & $\begin{array}{l}\text { Episode } \\
\text { Specialty }\end{array}$ & $\begin{array}{l}\text { Episode } \\
\text { HRG }\end{array}$ & $\begin{array}{l}\text { Episode } \\
\text { Cost }\end{array}$ & & & \\
\hline $\begin{array}{l}\text { May } \\
2012\end{array}$ & Daycases & $\begin{array}{l}\text { Pain } \\
\text { Management }\end{array}$ & $\mathrm{AB} 04 \mathrm{Z}$ & $£ 1,070$ & 20 & 1 & $£ 290$ \\
\hline
\end{tabular}

Source: Costings produced for the Business Case for the Pain Injection Centre at Gamma

In the above example, the total time in theatre is charged as 20 minutes, presumably to include preparation, recovery and support time. The "theatre cost" of $£ 290$ is the direct theatre costs for the patient, the Business Manager commented:

"That should be your theatre staffing cost and your theatre consumables." [BM-G]

Having demonstrated that the theatre was a high cost space in which to undertake routine pain injections, the Clinical Director and his Business Manager had to produce a business case based on indicative "bottom-up" patient level costs for the proposed new dedicated facility. They estimated that, on average, 11 patients could be treated as day cases during a four-hour session in the new centre, after being booked in through the Outpatient Department.

Table 5.6: Bottom up costs for the new pain injection centre (described as a theatre below)

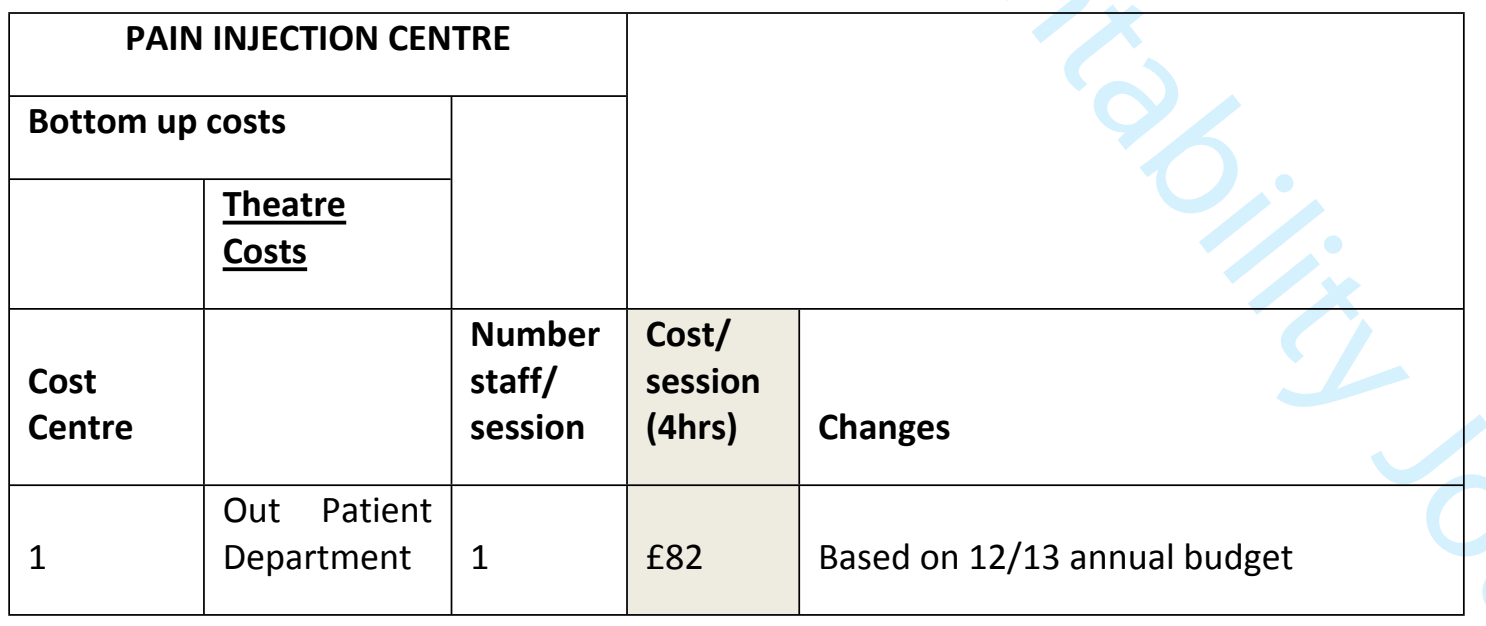




\begin{tabular}{|c|c|c|c|c|}
\hline 2 & Scrub & 1 & f63 & \\
\hline 3 & Recovery & 1.33 & f133 & Based on $12 / 13$ annual budget \\
\hline 4 & Support & 2 & $£ 45$ & No change from previous costing \\
\hline Radiology & Radiographer & 1 & f89 & No change from previous costing \\
\hline \multicolumn{3}{|c|}{$\begin{array}{l}\text { Total Theatre Staffing costs per } \\
\text { session }\end{array}$} & f412 & Staff costs advised by Pain Consultant \\
\hline 5 & \multicolumn{2}{|c|}{ Pain consultant } & £310 & Based on approximate rate per hour \\
\hline 6 & \multicolumn{2}{|c|}{ Theatre Consumables } & $£ 183$ & Based on 11 patients seen in 4 hours \\
\hline \multirow[t]{2}{*}{ Pharmacy } & \multicolumn{2}{|l|}{ Drugs } & $£ 307$ & \\
\hline & \multicolumn{2}{|c|}{ Overheads (14\%) } & £170 & $\begin{array}{l}14 \%{ }^{5} \text { based on current Injection centre } \\
\text { patient costing }\end{array}$ \\
\hline \multicolumn{3}{|c|}{$\begin{array}{l}\text { TOTAL COST PER SESSION } \\
\text { ( } 4 \text { HOURS) }\end{array}$} & $£ 1,381$ & \\
\hline & \multicolumn{2}{|c|}{ Tariff per patient } & $£ 602$ & \\
\hline & \multicolumn{2}{|c|}{$\begin{array}{l}\text { Income based on } 11 \\
\text { patients }\end{array}$} & $£ 6,622$ & \\
\hline & \multicolumn{4}{|c|}{3 patients required per session to cover costs } \\
\hline
\end{tabular}

Source: Pain Injection Centre costings, Gamma

The above costs show that, if 11 patients can be treated in a 240 minute session, the cost per patient in the new dedicated space would be $£ 125.55$, this implies, however, little more than 20 minutes for each patient because 11 patients would take 220 minutes. On this business case against a tariff of $£ 602$, the profit per patient in the new pain injection centre would be $£ 476.45$ as against the $f 468$ loss made on the sample patient in the high cost theatre. The Business Manager comments that each patient can be done in 15 minutes and the recovery time is no longer charged for:

"...[S]o we can see that actually, pain was a loss-making service. Because of the pain injection centre that's turned into a profit-making one....through the Injection Centre it's [each patient takes] every fifteen minutes. They also don't need to go into recovery after

${ }^{5}$ The figure of $14 \%$ for overheads for the pain injection centre is low compared with the literature, for example, Kalman et al. (2015) estimated US hospital overheads to be around $50 \%$ of total costs. In the UK, from our case study documents, we found overheads to be around $34 \%$. Nevertheless, the business case for the pain injection was successful. We can only assume that this $14 \%$ level of contribution was acceptable to the Board. 
theatre; they can just sit in like a chair, you know, so you're removing that cost as well." [BM-G]

Clearly the above calculations do not take account of the capital cost of the new centre. The Business Manager explains that new builds are through the Private Finance Initiative (PFI) and the service line at the hospital has a sufficiently good reputation to qualify.

"It's got a very good reputation this [hospital]. We've been able to take out PFI and loans and borrow against that kind of reputation. So you have to have a healthy balance sheet to be able to do that. But the investment and the new build that we've been able to dothat only comes from a strong balance sheet again." [BM-G]

Effectively, it appears that reporting a lower cost per patient in a new build facility negated any requirement for an assessment of the overall financial impact on the hospital of the transfer of patients out of theatres. Moreover, the capital cost of the new build was not considered but was treated as a taken-for-granted investment under a PFI.

\section{The stages in the episode}

In sum, this narrative explored the strategizing of the Clinical Director of Surgical Neurosciences and his wayfinding to practically cope with a loss-making service and its high transfer price charge. At Stage 1, the Clinical Director identified the "crude" nature of theatre transfer pricing which had fixed a single transfer price per minute across all users of its services as the reason pain injections were losing money for the service line. But rather than further practical coping through negotiating with theatres to establish a new transfer price, at Stage 2, the Clinical Director strategically focussed on the creation of a new space in the hospital - the pain injection centre. At Stage 3, the Clinical Director leveraged the good standing of his specialty with Finance to move directly to a business case, based on patient level costs for the new build facility. In doing so, he circumvented any complex and, possibly, conflictual negotiation with theatres to establish a lower transfer price for his pain injection patients. He also sidestepped any capital investment appraisal through building on the good reputation and "strong balance sheet" of the hospital. These attributes, seemingly, positioned the hospital very advantageously in securing PFIs. In consequence, a successful strategic outcome- the new dedicated facility- was achieved.

\section{Strategizing: Accounting, practical coping and strategic intent in English hospitals}

The three narratives trace strategizing pathways as the Clinical Directors practically coped with their Directorates' financial problems identifying when, through an engagement with accounting, strategic intent becomes evident on a pathway. Our contribution is to identify how agents may realise their immanent strategizing through their engagement with accounting practices.

\section{Practical coping, immanent strategies and accounting}

Our analysis highlights that the mode of engagement with accounting (in our cases, contesting, conforming or circumventing) can give practical coping an explicit strategic direction in addressing financial problems. Engagement with accounting through contesting, conforming or circumventing represents three possible coping patterns which capture the "internal logic of local coping actions" that take place "in situ in dealing with the exigencies of an evolving situation" 
(Chia \& Rasche, 2010, p.42). Research suggests that strategizing emerges through actors' internalized tendency and embodied disposition to purposively and instinctively act on what makes strategic sense (Chia \& Holt, 2006; Chia \& Rasche, 2010; Tsoukas, 2010). In all our strategizing episodes, when actors dealt with their emerging problems, an immanent strategy radiated through actors' purposive but non-deliberate everyday practice (Chia \& Holt, 2006; Chia \& MacKay, 2007; Chia \& Rasche, 2010). In this sense, as Chia and Mackay (2007) emphasise, strategizing is prompted by an engagement with a "field of practices". Clinical Directors, initially, had an overarching operational purpose to improve the financial position of their service, however as the pathways unfolded, Clinical Directors instinctively acted based on 'what made sense' while addressing their problems. Eventually, their latent strategic intent became manifest and observable. We argue that an engagement with accounting practices makes actors' immanent strategies manifest through substantiating their internalized propensity to act strategically. In doing so, we draw on the nuanced notions of strategies being "immanent" in practices which trigger actors' "internalized predisposition" to act strategically, as suggested by Chia and Holt (2006) and Chia and MacKay (2007) (and developed further by Chia and Rasche, 2010).

Our contribution is illustrated through our elucidation of the micro-actions through which strategic intent manifests and materializes around accounting. In the first narrative, the protagonist's strategic intent was evident through contestations around bad debt performance which formed the basis for negotiations with Finance. This is consistent with Samra-Fredericks (2003) who argues that strategizing becomes lived experience through talk-in-interaction, such as "negotiating, contesting, evaluating, blaming etc." (p. 167). In the second narrative, the Clinical Director conformed to the financial accountability rule that was enforced 'at the gates' (Jørgensen \& Messner, 2010). His strategic intent materializes through engaging with Finance and using patient-level costs in the business case. As such, in this second case, accounting mediated conflict, enabled the reconciliation of diverse interests and a shared understanding between our protagonist and senior management (cf. Cuganesan et al., 2012; Miller \& O'Leary, 2007). These findings complement previous studies which argue that, when different management levels interact, ad hoc 'strategic conversations' are, often, significant in trying to accommodate differing views (Hoon, 2007; Mantere, 2005). In the third narrative, however, the Clinical Director leveraged the financial standing of his specialty and the business case to avoid negotiations with theatres over transfer pricing and evade capital investment appraisals. This finding contradicts previous studies which highlight the significance of accounting discourse in promoting dialogue and resolving conflict (e.g. Ahrens \& Chapman, 2007; Jørgensen \& Messner, 2010). We add to discussions of micro-actions in strategizing by arguing that circumventing accounting can materialize actors' strategic intent without negotiation, through sidestepping conflict and eschewing financial accountability.

\section{Accounting, agency and the power of numbers in strategizing}

Our analysis also emphasizes the power of numbers in strategizing (cf. Denis et al., 2006). Fauré and Rouleau (2011) suggest that managers' strategic competence in strategizing is conversationally performed through discussions around numbers, arguing that "talk is action" (p.179). This is evident mainly in the first narrative, where the protagonist's strategizing is mostly realized through verbal negotiations with Finance. Through strategizing discourses, the Clinical Director assumed the power to contest imposed financial rules and processes. In this contestation, she expressed her resentment and became less cooperative (cf. Ezzamel \& Willmott, 2008). In the other two narratives, strategizing was substantiated through tangible, 
number-based business cases which adhered to concrete organizational rules and signalled verifiable cost efficiencies. In all our narratives, accounting became relevant and powerful when coupled with the practical coping of our actors in strategically resolving the immediate financial problems of their Directorate. However, it was only when protagonists constructed their own accounting through business cases that our actors' problems were resolved. Our findings complement previous studies which advocate that, in strategizing, numbers are more powerful than words (Denis et al., 2006; Whittle \& Mueller, 2010) and demonstrate how strategizing highlights the power of accounting in complex situations (Denis et al., 2006; Jørgensen \& Messner, 2010). Arguably, if the Clinical Director at Alpha had coupled her verbal contestations with accounting evidence on the central services' poor performance and her Directorate's projected performance from running such services, perhaps chasing bad debt from within her Directorate would have come to fruition.

Our analysis also reveals how accounting supports strategizing agency. In our episodes, actors employed an assemblage of accounting tools and artefacts to steer their contesting, conforming and circumventing within their navigational sphere. Specifically, our protagonists used accounting devices (e.g. Skærbæk \& Tryggestad, 2010) such as business cases, artefacts such as spreadsheets and PowerPoint slides (e.g. Jarzabkowski et al., 2013), tools and 'number systems' (Denis et al., 2006) such as patient-level costing systems and service line reporting. These 'technologies of rationality' (Jarzabkowski \& Kaplan, 2015) provided Clinical Directors with the power to strategically contest bad debt, conform to capital investment rules and circumvent transfer price charges, as they used accounting contextually to inform each turn of their strategizing pathways (Ahrens \& Chapman, 2007; Jørgensen \& Messner, 2010; Skærbæk \& Tryggestad, 2010; see also Nama \& Lowe, 2014). Accounting, as the proverbial compass, pointed the way towards a potential solution to our actors' problems and steered them towards the next iteration of their strategizing. This echoes Chia and Holt (2006, p. 651) who argue that strategizing addresses the question "Where are we now?" and simultaneously offers insight into an implicit, context-sensitive map which answers the strategic question of "Where do we want to go?". We enrich such discussions through suggesting that accounting delivers an answer to the significant question of 'How do we get there?' when immersed in a complex strategizing episode. We add to the discussion of strategizing agency (e.g. Boedker, 2010; Carter et al., 2008; Maclntosh \& Beech, 2011; Tsoukas, 2010), by arguing that the strong presence of accounting devices and number-based texts, such as patient-level costing systems, have the potential to manifest the strategic intent of Clinical Directors.

\section{Concluding comments}

This paper investigates accounting in the unfolding of strategizing in pluralistic organizations. To date, there has been scant empirical research into the interplay between pluralism, accounting and strategizing. Also, within the work on strategizing, there is little clarity on when practical coping takes on an explicit strategic direction. We show how accounting can begin in practical coping but may also offer a number-based bridge into overt strategic intent. Strategizing is particularly prevalent in pluralistic settings which embed diffuse power. Dwelling in a milieu such as a profit centre - can lead agents to mobilise accounting practices in pursuit of localised strategies, which may deviate from organizational objectives. The nexus of pluralism, strategizing and accounting offers rich opportunities for observing agents' transition from practical coping to explicit strategic intent within their bounded localities. 


\section{References}

Aggerholm, H. K., Asmuß, B., \& Thomsen, C. (2012). The role of recontextualization in the multivocal, ambiguous process of strategizing. Journal of Management Inquiry, 21(4), 413-428.

Ahrens, T., \& Chapman, C. S. (2007). Management accounting as practice. Accounting, Organizations and Society, 32(1), 1-27.

Balogun, J., Huff, A. S., \& Johnson, P. (2003). Three Responses to the Methodological Challenges of Studying Strategizing*. Journal of Management Studies, 40(1), 197-224.

Balogun, J., Best, K., \& Lê, J. (2015). Selling the Object of Strategy: How frontline workers realize strategy through their daily work. Organization Studies, 36(10), 1285-1313.

Begkos, C. (2016). Accounting and strategizing: medical managers' use of accounting information (Doctoral dissertation). Retrieved from the University of Manchester Library

Boedker, C. (2010). Ostensive versus performative approaches for theorising accounting-strategy research. Accounting, Auditing \& Accountability Journal, 23(5), 595-625.

Brunsson, N. (1989). The Organization of Hypocrisy: Talk, Decisions and Actions in Organizations, John Wiley \&Sons: UK.

Brunsson, N. (1993). Ideas and actions: Justification and hypocrisy as alternatives to control. Accounting, Organizations and Society, 18(6), 489-506.

Brunnson, N. (2000). The Irrational Organization, $2^{\text {nd }}$ Edition, Copenhagen Business School

Bryman, A. (2016). Social research methods. Oxford university press.

Carter, C., Clegg, S. R., \& Kornberger, M. (2008). Strategy as practice. Strategic Organization, 6(1), 83-99.

Carter, C., Clegg, S., \& Kornberger, M. (2010). Re-framing strategy: power, politics and accounting. Accounting, Auditing \& Accountability Journal, 23(5), 573-594.

Chandler, A. D. (1962). Strategy and structure. Cambridge, MA: MIT Press

Chia, R., \& Holt, R. (2006). Strategy as practical coping: A Heideggerian perspective. Organization Studies, 27(5), 635-655.

Chia, R., \& MacKay, B. (2007). Post-processual challenges for the emerging strategy-as-practice perspective: Discovering strategy in the logic of practice. Human relations, 60(1), 217-242.

Chia, R., \& Rasche, A. (2010). Building and dwelling world-views-Two alternatives for researching strategy as practice. In Golsorkhi D., Seidl D., Rouleau L., Vaara E.(Eds.), Cambridge handbook of strategy as practice, 34-46. Cambridge: Cambridge University Press

Chua, W. F. (2007). Accounting, measuring, reporting and strategizing-Re-using verbs: A review essay. Accounting, Organizations and Society, 32(4), 487-494.

Cooper, D. J., \& Morgan, W. (2008). Case study research in accounting. Accounting Horizons,22(2), 159-178.

Cuganesan, S., Dunford, R., \& Palmer, I. (2012). Strategic management accounting and strategy practices within a public sector agency. Management Accounting Research, 23(4), 245-260. 
Czarniawska, B. (2004). Narratives in social science research. Sage.

Denis, J. L., Lamothe, L., \& Langley, A. (2001). The dynamics of collective leadership and strategic change in pluralistic organizations. Academy of Management journal, 44(4), 809-837.

Denis, J. L., Langley, A., \& Rouleau, L. (2006). The power of numbers in strategizing. Strategic Organization, 4(4), 349-377.

Denis, J. L., Langley, A., \& Rouleau, L. (2007). Strategizing in pluralistic contexts: Rethinking theoretical frames. Human Relations, 60(1), 179-215.

Department of Health. (2002). Delivering the NHS plan: next steps on investment, next steps on reform. Department of Health Publications

Department of Health. (2010). Review of access to the NHS by foreign nationals. Consultation on proposals. Department of Health Publications

Department of Health. (2016). Reference costs 2015-16. Department of Health Publications

Eisenhardt, K. M. (1989). Building theories from case study research. Academy of management review, 14(4), 532-550.

Eisenhardt, K. M., \& Graebner, M. E. (2007). Theory building from cases: Opportunities and challenges. Academy of management journal,50(1), 25-32.

Ezzamel, M., \& Willmott, H. (1993). Corporate governance and financial accountability: recent reforms in the UK public sector. Accounting, Auditing \& Accountability Journal, 6(3), 0-0.

Ezzamel, M., \& Willmott, H. (2008). Strategy as discourse in a global retailer: A supplement to rationalist and interpretive accounts. Organization Studies, 29(2), 191-217.

Ezzamel, M., \& Willmott, H. (2010). Strategy and strategizing: A poststructuralist perspective. Advances in Strategic Management, 27, 75-109.

Fauré, B., \& Rouleau, L. (2011). The strategic competence of accountants and middle managers in budget making. Accounting, Organizations and Society, 36(3), 167-182.

Guest, G., MacQueen, K. M., \& Namey, E. E. (2011). Applied thematic analysis. Sage.

Hall, M. (2017). Crafting Compromises in a Strategising Process: A Case Study of an International Development Organisation. Financial Accountability \& Management, 33(2), 171-191.

Hamel, G., \& Prahalad, C. K. (1990). Strategic intent. Harvard Business Review, 68(3), 18-38.

Hendry, J., \& Seidl, D. (2003). The structure and significance of strategic episodes: Social systems theory and the routine practices of strategic change. Journal of management Studies, 40(1), 175196.

Heidegger, M. (1971). Poetry, Language, Thought. Translations and Introd. By Albert Hofstadter.

Hoon, C. (2007). Committees as strategic practice: The role of strategic conversation in a public administration. Human Relations, 60(6), 921-952.

Hutchins, E. (1995). Cognition in the Wild. MIT press.

Hydle, K. M. (2015). Temporal and Spatial Dimensions of Strategizing. Organization Studies,36(5), 643-663. 
Jacobs, K. (2005). Hybridisation or polarisation: doctors and accounting in the UK, Germany and Italy. Financial Accountability \& Management, 21(2), 135-162.

Jacobs, C., \& Heracleous, L. (2007). Strategizing through playful design.Journal of Business Strategy, 28(4), 75-80.

Jarzabkowski, P., Balogun, J., \& Seidl, D. (2007). Strategizing: The challenges of a practice perspective. Human relations, 60(1), 5-27.

Jarzabkowski, P., \& Fenton, E. (2006). Strategizing and organizing in pluralistic contexts. Long Range Planning, 39(6), 631-648.

Jarzabkowski, P., \& Kaplan, S. (2015). Strategy tools-in-use: A framework for understanding "technologies of rationality" in practice. Strategic Management Journal, 36(4), 537-558.

Jarzabkowski, P., \& Seidl, D. (2008). The role of meetings in the social practice of strategy. Organization studies, 29(11), 1391-1426.

Jarzabkowski, P., Spee, A. P., \& Smets, M. (2013). Material artifacts: Practices for doing strategy with 'stuff'. European management journal, 31(1), 41-54.

Johnson, G., Melin, L., \& Whittington, R. (2003). Micro strategy and strategizing: towards an activity-based view. Journal of management studies, 40(1), 3-22.

Jørgensen, B., \& Messner, M. (2010). Accounting and strategising: A case study from new product development. Accounting, Organizations and Society,35(2), 184-204.

Kalman, N., Hammill, B., Schulman, K., \& Shah, B. (2015). Hospital overhead costs: the neglected driver of health care spending?. Journal of health care finance, 41(4).

Kirkpatrick, I., Bullinger, B., Dent, M., \& Lega, F. (2012). The development of medical-manager roles in European hospital systems: a framework for comparison. International journal of clinical practice,66(2), 121-124.

Kurunmäki, L. (2004). A hybrid profession-the acquisition of management accounting expertise by medical professionals. Accounting, organizations and society, 29(3), 327-347.

Lê, J. K., \& Jarzabkowski, P. A. (2015). The role of task and process conflict in strategizing. British Journal of Management, 26(3), 439-462.

Llewellyn, S. (1999). Narratives in accounting and management research.Accounting, Auditing \& Accountability Journal, 12(2), 220-237.

Llewellyn, S. (2001). Two-way windows': clinicians as medical managers. Organization Studies, 22(4), 593-623.

Llewellyn, S., Chambers, N., Ellwood, S., Begkos, C., \& Wood, C. (2016). Patient-level information and costing systems (PLICSs): a mixed-methods study of current practice and future potential for the NHS health economy.

Luhmann, N. (1990). 'Anfang und Ende: Probleme einer Unterscheidung'. In Luhmann, N. and Schorr, K. (Eds), Zwischen Anfang und Ende: Fragen an die Pddagogik. Frankfurt a.M.: Stihrkamp, 11-23.

Luhmann, N. (1995). Social systems. Stanford University Press. 
Maclntosh, R., \& Beech, N. (2011). Strategy, strategists and fantasy: a dialogic constructionist perspective. Accounting, Auditing \& Accountability Journal, 24(1), 15-37.

Maitlis, S., \& Lawrence, T. B. (2003). Orchestral manoeuvres in the dark: Understanding failure in organizational strategizing. Journal of Management Studies, 40(1), 109-139.

Mantere, S. (2005). Strategic practices as enablers and disablers of championing activity. Strategic organization, 3(2), 157-184.

Mantere, S. (2008). Role expectations and middle manager strategic agency.Journal of Management Studies, 45(2), 294-316

Mantere, S., \& Sillince, J. A. (2007). Strategic intent as a rhetorical device. Scandinavian Journal of Management, 23(4), 406-423.

Miller, P., \& O'Leary, T. (2007). Mediating instruments and making markets: Capital budgeting, science and the economy. Accounting, organizations and society, 32(7), 701-734.

Minzberg, H. (1987). Crafting strategy, Harvard Business Review, July-August: 66-75

Monitor. (2006). Service-line reporting: How SLR can improve productivity and performance in NHS foundation trusts. Part of: Service-line management: an approach to hospital management. Monitor

Nama, Y., \& Lowe, A. (2014). The 'situated functionality' of accounting in private equity practices: A social 'site' analysis. Management Accounting Research, 25(4), 284-303.

Nyland, K., \& Pettersen, I. J. (2004). The Control Gap: The Role of Budgets, Accounting Information and (Non-) Decisions in Hospital Settings. Financial Accountability \& Management, 20(1), 77-102.

O'Shannassy, T. F. (2016). Strategic intent: The literature, the construct and its role in predicting organization performance. Journal of Management \& Organization, 22(5), 583-598.

Regnér, P. (2003). Strategy creation in the periphery: inductive versus deductive strategy making. Journal of management studies, 40(1), 57-82.

Rouleau, L., \& Balogun, J. (2011). Middle managers, strategic sensemaking, and discursive competence. Journal of Management Studies, 48(5), 953-983.

Rouleau, L. (2005). Micro-Practices of Strategic Sensemaking and Sensegiving: How Middle Managers Interpret and Sell Change Every Day*.Journal of Management Studies, 42(7), 14131441.

Samra-Fredericks, D. (2003). Strategizing as Lived Experience and Strategists' Everyday Efforts to Shape Strategic Direction*. Journal of Management Studies, 40(1), 141-174.

Scapens, R. W. (1990). Researching management accounting practice: the role of case study methods. The British Accounting Review, 22(3), 259-281.

Scapens, R. W. (2004). Doing case study research. In Humphrey, C., \& Lee, B. H. (Eds.), The real life guide to accounting research: a behind-the-scenes view of using qualitative research methods, 257-279. Elsevier.

Skærbæk, P., \& Tryggestad, K. (2010). The role of accounting devices in performing corporate strategy. Accounting, Organizations and Society, 35(1), 108-124. 
Spee, A. P., \& Jarzabkowski, P. (2011). Strategic planning as communicative process. Organization Studies, 32(9), 1217-1245.

Street, A., \& Maynard, A. (2007). Activity based financing in England: the need for continual refinement of payment by results. Health Economics, Policy and Law, 2(04), 419-427.

Tsoukas, H. (2010). Practice, strategy making and intentionality: a Heideggerian ontoepistemology for strategy as practice. In Golsorkhi D., Seidl D., Rouleau L., Vaara E.(Eds.), Cambridge handbook of strategy as practice, 47-62. Cambridge: Cambridge University Press

Vaara, E., \& Whittington, R. (2012). Strategy-as-practice: taking social practices seriously. The Academy of Management Annals, 6(1), 285-336.

Webb, A. L., \& Wistow, G. (1982). Whither state welfare?: Policy and implementation in the personal social services, 1979-80 (Vol. 8). Royal Institute of Public Administration

Weick, K. E. (1969). The Social Psychology of Organizing. Reading, MA: Addison-Wesley.

Whittington, R. (1996). Strategy as practice. Long range planning, 29(5), 731-735.

Whittington, R. (2003). The work of strategizing and organizing: for a practice perspective. Strategic organization, 1, 117-126.

Whittington, R. (2006). Completing the practice turn in strategy research. Organization studies, 27(5), 613-634.

Whittle, A., \& Mueller, F. (2010). Strategy, enrolment and accounting: the politics of strategic ideas. Accounting, Auditing \& Accountability Journal, 23(5), 626-646.

Yin, R. K. (2003). Case study research: Design and methods. Sage publications.

\section{Appendix}

List of interviews pertaining to each narrative

\begin{tabular}{|c|c|c|c|c|c|}
\hline$\#$ & Job Title & Case Study & Date & Duration & Abbreviation \\
\hline 1 & $\begin{array}{l}\text { Clinical Director of } \\
\text { Women's Services }\end{array}$ & Alpha & $\begin{array}{l}18 / 03 / 2014, \\
14 / 05 / 2015\end{array}$ & $\begin{array}{l}00: 50: 44, \\
00: 21: 14\end{array}$ & {$[C D-A]$} \\
\hline 2 & $\begin{array}{l}\text { Deputy Director of } \\
\text { Finance }\end{array}$ & Alpha & $\begin{array}{l}10 / 05 / 2013 \\
10 / 03 / 2014\end{array}$ & $\begin{array}{l}00: 54: 15 \\
01: 32: 02\end{array}$ & [F1-A] \\
\hline 3 & $\begin{array}{l}\text { Director of } \\
\text { Operations }\end{array}$ & Alpha & $14 / 06 / 2013$ & $00: 54: 14$ & [OD-A] \\
\hline 4 & $\begin{array}{l}\text { Clinical Director } \\
\text { of Haematology }\end{array}$ & Beta & $30 / 09 / 2013$ & $00: 57: 44$ & [CD-B] \\
\hline 5 & $\begin{array}{c}\text { Deputy Director } \\
\text { of Finance }\end{array}$ & Beta & $10 / 12 / 2013$ & $00: 54: 00$ & [F1-B] \\
\hline 6 & Finance Manager & Beta & $14 / 08 / 2013$ & 01:02:00 & {$[\mathrm{F} 2-\mathrm{B}]$} \\
\hline 7 & $\begin{array}{c}\text { Interim Chief } \\
\text { Exec }\end{array}$ & Beta & $01 / 04 / 2014$ & 01:10:29 & [CE-B] \\
\hline
\end{tabular}




\begin{tabular}{cccccc}
\hline 8 & $\begin{array}{c}\text { Clinical Director of } \\
\text { Surgical } \\
\text { Neurosciences }\end{array}$ & Gamma & $31 / 03 / 2014$ & $00: 59: 38$ & [CD1-G] \\
\hline 9 & $\begin{array}{c}\text { Clinical Director of } \\
\text { Theatres }\end{array}$ & Gamma & $28 / 01 / 2014$ & $00: 51: 25$ & [CD2-G] \\
\hline 10 & $\begin{array}{c}\text { Business Manager } \\
\text { of Neurosurgery }\end{array}$ & Gamma & $30 / 04 / 2014$ & $00: 20: 21$ & {$[\mathrm{BM}-\mathrm{G}]$} \\
\hline
\end{tabular}

List of documents pertaining to each narrative

\begin{tabular}{|c|c|c|c|c|c|}
\hline$\#$ & Document & About & Case & Date & Pages \\
\hline 1 & Performance review & Women's services & Alpha & Apr-14 & 1 \\
\hline 2 & Financial review & Integrated Unit & Beta & May-12 & 78 \\
\hline 3 & Financial Review & Haematology & Beta & & 20 \\
\hline 4 & Presentation & Introducing PLICS & Beta & & 22 \\
\hline 5 & Pain injection Costings & Pain injection centre & Gamma & May-12 & Excel \\
\hline
\end{tabular}

